\title{
TTR
}

Traduction, terminologie, re?daction

\section{Lawrence Venuti (Guest Editor). Translation and Minority, special issue, The Translator. Studies in Intercultural Communication. Volume 4, Number 2, 1998.}

\section{Paul Bandia}

Volume 13, numéro 2, 2e semestre 2000

Les Antilles en traduction

The Caribbean in Translation

URI : https://id.erudit.org/iderudit/037422ar

DOI : https://doi.org/10.7202/037422ar

Aller au sommaire du numéro

Éditeur(s)

Association canadienne de traductologie

ISSN

0835-8443 (imprimé)

1708-2188 (numérique)

Découvrir la revue

Citer ce compte rendu

Bandia, P. (2000). Compte rendu de [Lawrence Venuti (Guest Editor).

Translation and Minority, special issue, The Translator. Studies in Intercultural Communication. Volume 4, Number 2, 1998.] TTR, 13(2), 264-268.

https://doi.org/10.7202/037422ar d'utilisation que vous pouvez consulter en ligne.

https://apropos.erudit.org/fr/usagers/politique-dutilisation/ 
Paul St-Pierre

Université de Montréal

\section{Lawrence Venuti (Guest Editor). Translation and Minority, special issue, The Translator. Studies in Intercultural Communication. Volume 4, Number 2, 1998.}

Translation and Minority is the title of a special issue of The Translator, edited by Lawrence Venuti. The volume is made up of articles, book reviews, a course profile and a selective bibliography on minority issues in translation studies. The articles cover a wide range of geo-political and socio-cultural situations and deal with samples of the multilingual cultures of Africa, Asia, Europe and North America. Translation and Minority is innovative and refreshing in that it goes beyond the much-too-familiar binary opposition of the Third World versus the developed world, and includes articles on the minority situations that exist within the geographical confines of some industrialized nations. Also, it is interesting to note the evenhandedness with which the term 'minority' is used in this volume, as a double-edged sword, so-to-speak, cutting both ways to explore the assertions that minority translating can be a majoritizing as well as a minoritizing entreprise. Minority translating, it is argued, can serve to minoritize dominant or majoritarian cultures through diverse procedures of variation; by the same token, minority translating can pave the way for hegemonic or majoritarian incursions into a minor culture thus reinforcing its minority status. For instance, Piotr Kwieciski's article shows how since the collapse of the socialist state in Poland the Polish language has succumbed to the global domination of English, absorbing Anglo-American items and resulting in the variation of standard Polish through translation. However, standard English is also varied or altered due to contact with Polish, resulting in a variety which is neither quite British nor American, but rather a Polish variety of English, hybridized through translation.

Lawrence Venuti's broad definition of the concept of minority casts a wide net which allows for the collage of a great number of disparate articles into a cohesive volume. In the introduction to this volume, Venuti establishes its epistemological and theoretical 
framework, setting out its objectives and welding together the various contributions into a rare and valuable treatment of the issue of minority in translation. Inspired by Deleuze and Guattari's poststructuralist theories of language and textuality, Venuti creates a parallel between the concepts of 'minor literature' and 'minority translating'. Deleuze and Guattari outline three features that characterize a 'minor literature', namely (a) deterritorialization of language (b) political immediacy and (c) collective assemblage of enunciation. Venuti extends these features to account for translation in a minor culture, and attempts to group the articles in this volume under these three features as headings. Although this is a commendable effort to provide a logical structure in the organization of the volume, the boundaries are somewhat blurred as the groupings are not mutually exclusive and some items may overlap. For instance, Adejunmobi's article on translating anglophone and francophone African novels is as much about collective assemblage as it is about deterritorialization.

The following articles are particularly insightful illustrations of collective assemblage of enunciation through minority translating: Piotr Kwieciski's paper on the role of translation in determining the impact of English on Polish in a post-socialist Poland; Moradewun Adejunmobi's analysis of the vital role of translation in projecting national cultures and literatures in a postcolonial context; and Loredana Polezzi's discussion of travel writing as cultural translation. These papers (and others in the volume) demonstrate the fact that minority translating is not simply a means of self-expression, or an idiosyncratic, individualistic experimentation, but rather an expression of an assemblage of forms and discourses in order to characterize one's linguistic community, ethnicity, gender, or sexuality. For Adejunmobi, the attempt by some African postcolonial writers to indigenize colonial languages is not merely a quest for authorial recognition through original self-expression, but rather a desire to project transnational identities by highlighting the translingualism prevalent in postcolonial situations, and by subverting the dominant lingua franca which are a part of the colonial legacy. Polezzi studies three Italian traveler-writers and their books on Tibet and points out that although the writers present themselves as individual authors, each having a personal relationship with Tibet, they do share a collective viewpoint determined by generic conventions, institutional images, colonial and nationalist ideologies which in turn shapes, and responds to, the untravelled home reader's perception of the Other. 
The volume also features a few articles dealing with political immediacy as a feature of minority translating. Kathy Mezei discusses how a bilingual poem, Michèle Lalonde's Speak White (1968) had helped to galvanize the Québécois élite by focusing their desire for political independence. Silvia Coll-Vinent shows how pre-World War II Catalan translators strove to overcome the limitations of the Catalan novelistic tradition by translating British novels from the Victorian and Edwardian era. They did this however through the mediation of the French tradition which had a decisive influence on the choice of translation strategies. Eric Keenaghan's paper deals with the American poet Jack Spicer's use of translation in the 1950s to enlist Federico Garcia Lorca's writing in a gay cultural politics. Finally, Nam Fung Chang discusses his Chinese translation of Yes Prime Minister, a British political comedy, and how it was cast as a satire of the Chinese socialist government in order to enhance the efforts of the embattled Democratic Movement. These articles deal with instances of immediate politicization of language and literature, and highlight the fact that minority translation strategies can constitute a political act.

Deterritorialization of language as a feature of minority translating is also dealt with extensively in this special issue. Michael Cronin's paper highlights what he refers to as "heteroglossia", a byproduct of minority translating, and its impact on the dominant language. Minority translating practices are highly inventive and can thus destabilize the dominant language by enhancing linguistic multiplicity and hybridity. Keith Harvey argues that translating in any cultural or political context can either be majoritarian or minoritarian as translation becomes a form of rewriting of the foreign text to conform to, or support, the dominant values in the translating culture. Harvey opposes a majoritarian example, a French translator's deliberate omission of camp talk in an American novel about gay men in an attempt to conform to the French perception of the Enlightenment notions of universal humanity (p. 310), to a minoritarian example, an American translator who carefully reproduced the camp assigned to a character in a French novel thus highlighting the homosexual message of the novel. This translation strategy accounts for the more militant approach to sexual identity in Anglo-American culture.

Although minor translating is often defined in terms of how it submits the majority to variation, minor translating can also enhance the heterogeneity of minor cultures, and can trigger an uncontrollable process of deterritorialization. Minority translating does not guarantee 
that the target culture will remain free of the influences of the dominant language. For example, Kwieciski shows how in Poland the translation of Anglo-American texts "appear to recreate in Polish the way the dominant Anglo-American culture views the weaker culture" (p. 203), thus reproducing cultural stereotypes and emphasizing Poland's minority status. Therefore, minority translating does not necessarily ensure a homogenizing process of identity formation and autonomy. As any form of translating can result in unexpected cultural and political changes, the cultural and social effects of minority translating are still largely unpredictable.

There is growing interest in minority translating as shown by the great variety of papers in this volume. Minority translating has the potential to significantly broaden the scope of research in translation studies as it opens up new approaches inspired by recent developments in other disciplines and discourses such as feminism, psychoanalysis, poststructuralism, postcolonialism and gay/lesbian studies. The interdisciplinary nature of minority translating research allows for the inclusion of other theoretical and political discourses which are likely to account for marginalized languages, literatures and cultures in translation studies. Translation studies has been identified for a long time with majoritarian approaches whose objectives have been to establish scientific models based on universalizing theories. These universalizing theories are not inherently flawed insofar as they have provided the tools for a formal analysis of language and textuality. However, as Venuti points out in his introduction to this volume, "any effort to specify the minor situation requires that such tools be accompanied by the reconstruction of cultural and political contexts and a revision of universalizing theoretical concepts" (p. 143). Indeed, disciplines such as sociolinguistics, discourse analysis and pragmatics have made inroads into translation studies and have shifted the focus from studying mainly standard varieties to studying non-standard, or marginalized, language cultures. These new approaches which thrive on their quest for understanding linguistic and cultural differences, seem better equipped to study peripheral or minority situations.

The articles included in this special issue of The Translator demonstrate that translation research can be expanded to include a wide variety of theories to account for translational situations outside the universalizing mainstream context. The concept of minority in translation studies is broad enough to include various media, genres and practices. The articles in this volume deal with a variety of minor 
situations ranging from print journalism and television voiceovers to travel writing and bilingual poetry, translingualism and software localization.

In the current climate of globalization, minority translating research can help preserve and develop peripheral languages and cultures providing them with the backbone they need to resist the universalizing influences of hegemonic cultures.

Paul Bandia

Concordia University 